\title{
Non-Steroidal Aromatase Inhibitor
}

National Cancer Institute

\section{Source}

National Cancer Institute. Non-Steroidal Aromatase Inhibitor. NCI Thesaurus. Code C2018.

An aromatase inhibitor with a non-steroidal structure. Non-steroidal aromatase inhibitors work by reversible competition with the enzyme. 